\title{
Noctuidae moths occurring in grape orchards in Serra Gaúcha, Brazil and their relation to fruit-piercing
}

\author{
Maurício Moraes Zenker ${ }^{1}$, Marcos Botton², José Augusto Teston³ \& Alexandre Specht",5
}

${ }^{1}$ Laboratório de Entomologia, Departamento de Biodiversidade e Ecologia, Faculdade de Biociências, Pontifícia Universidade Católica do Rio Grande do Sul. Av. Ipiranga, 6681, 90619-900 Porto Alegre-RS, Brasil. maurizenker@yahoo.com.br.

${ }^{2}$ Laboratório de Entomologia, Centro Nacional de Pesquisa em Uva e Vinho, Rua Livramento, 515, Caixa Postal 130, 95700-000 Bento Gonçalves-RS, Brasil.

3Programa de Ciências Biológicas, Universidade Federal do Oeste do Pará, Av. Marechal Rondon, s/n, 68040-070 Santarém-PA, Brasil. jateston@ufpa.br.

${ }^{4}$ Laboratório de Biologia, Centro de Ciências Exatas, da Natureza e de Tecnologia, Campus Universitário da Região dos Vinhedos, Universidade de Caxias do Sul, Caixa Postal 32, 95700-000 Bento Gonçalves-RS, Brasil. aspecht@ucs.br.

${ }^{5}$ Instituto de Biotecnologia, Centro de Ciências Agrárias e Biológicas, Universidade de Caxias do Sul, Cidade Universitária, Caixa Postal 1352, 95070-560 Caxias do Sul-RS, Brasil.

\begin{abstract}
Noctuidae moths occurring in grape orchards in Serra Gaúcha, Brazil and their relation to fruit-piercing. There is no study aiming to investigate if Noctuidae moths are responsible for piercing cultivated fruits in South America. This research aims to survey noctuid moths and list the species with mouth-parts (proboscis) morphology that suggest the capacity to cause damages to grape orchards in the state of Rio Grande do Sul, Brazil. Catches were carried out weekly from late November 2007 to late March 2008 (fructification period) using light traps and McPhail traps in three grape orchards in the region of Serra Gaúcha. The catches resulted in 187 taxa, with 149 identified at the specific level and 38 at genus level. The proboscises of representative taxa were removed and analyzed under stereomicroscope and scan electron microscope. It was verified that only Oraesia argyrosema (Hampson, 1926) and Gonodonta biarmata Guenée, 1852 show proboscis with suitable morphology for piercing rind and pulp of a grape berry. Achaea ablunaris (Guenée, 1852); Ascalapha odorata (Linnaeus, 1758); Letis mineis Geyer, 1827; Mocis latipes Hübner, 1823; Ophisma tropicalis Guenée, 1852, and Zale exhausta (Guenée, 1852) show proboscis only adapted to lacerate the pulp. The proboscis morphology of the remaining noctuid moths suggests lack of capacity to cause damage. Despite the presence of species capable of piercing grape berries, the populations of such species are very reduced and unable to cause damage of economic level.
\end{abstract}

KEYWORDS. Bait; fruit-piercing moths; light trap; McPhail trap; proboscis.

RESUMO. Mariposas Noctuidae presentes em parreirais na Serra Gaúcha, Brasil e sua relação com a perfuração dos frutos. Na América do Sul inexistem estudos que investiguem se noctuídeos adultos são responsáveis pela perfuração de frutos cultivados. Visando avaliar a ocorrência e listar as espécies que apresentam aparelho bucal (espirotromba) com morfologia que sugira a capacidade de causar danos à cultura da uva no Rio Grande do Sul, Brasil, foram realizadas coletas semanais entre o final de novembro de 2007 e o final de março de 2008 (período de frutificação) utilizando armadilhas luminosas e McPhail em três áreas de cultivo na Serra Gaúcha. As coletas resultaram em um total de 187 táxons, sendo 149 identificados ao nível específico e 38 ao nível genérico. A espirotromba de cada táxon identificado foi retirada e analisada em microscópio estereoscópio e microscópio eletrônico de varredura. Foi constatado que apenas Oraesia argyrosema (Hampson, 1926) e Gonodonta biarmata Guenée, 1852 apresentam espirotromba com morfologia própria para perfurar a casca e a polpa da baga da uva. Achaea ablunaris (Guenée, 1852); Ascalapha odorata (Linnaeus, 1758); Letis mineis Geyer, 1827; Mocis latipes Hübner, 1823; Ophisma tropicalis Guenée, 1852 e Zale exhausta (Guenée, 1852) apresentam espirotromba capaz apenas de dilacerar a polpa. As demais espécies apresentam espirotromba com morfologia inadequada para causar danos desta natureza. Apesar de ter sido constatada a presença de noctuídeos adultos capazes de perfurar bagas de uva, as populações destas espécies encontram-se muito reduzidas para causar danos econômicos.

PALAVRAS-CHAVE. Armadilha-luminosa; armadilha McPhail; isca; mariposas perfuradoras de frutos; probóscide.

Some noctuid moths, specially in the subfamily Calpinae (sensu Lafontaine \& Fibiger 2006), show mouth-parts adapted to pierce both rind and pulp of fruits (Mosse-Robinson 1968), causing direct damage (primary fruit-piercing moths), whereas other species are just capable to cause indirect damage dispersing microorganisms by piercing the exposed pulp of already damaged fruits and inducing rottenness (secondary fruit-piercing moths) (Bänziger 1970).

Fruit-piercing moths occur mainly in the tropical regions, though the world occurrence of this kind of fauna is still unknown (Fay \& Halfpapp 2006). The most important species, Eudocima fullonia (Clerck, [1874]) (Calpinae), occurring in Africa and Oceania is capable to feed on more than 100 species of fruits, including cultivated and native (Davis et al. 2005). There are reports of fruit damage in the Neotropical region for Central America, Mexico, and Jamaica (Anonymous apud Mosse-Robinson 1968). For the U.S.A., there are reports of damage caused in orange orchards in the state of Florida (King \& Thompson 1958). In South America, Haji et al. (2001) reported a single case of damage caused by fruit-piercing moths. These authors verified damage in grape orchard in the Brazilian northeast region of Vale do Rio São Francisco during pest monitoring programs.

For the Serra Gaúcha region, in the Brazilian southernmost 
state of Rio Grande do Sul, which have the largest grape cultivated area in the country, there are no bibliographical data about damage caused by fruit-piercing moths. However, many producers reported massive presence of moths during the harvesting period and have associated their occurrence with damage similar to those caused by fruit-piercing moths.

This study was based upon the suspect of potential damage that would be caused by fruit-piercing moths and the presence of species of Calpinae in Rio Grande do Sul (Specht \& Corseuil 1996, 1998, 2001, 2002a; Specht et al. 2004), and aimed: (1) to survey species diversity and abundance of noctuid moths occurring in grape orchards in Serra Gaúcha during ripening period; (2) to investigate the mouth-parts morphology of each species looking for evidence that corroborate to their piercing suitability; (3) to characterize the mouth-parts morphology of species capable to cause primary and/or secondary damage, and those of the species not capable to cause damage to grape berries.

\section{MATERIAL AND METHODS}

Insects and taxonomic state. The highest taxonomic categories included in this survey follow the systematic classification proposed for Noctuidae sensu Lafontaine \& Fibiger (2006) that considered Arctiidae and Lymantriidae as subfamilies of Noctuidae. However, due to limitations of this classification at generic and specific level and aiming to allow the comparison with prior diversity studies of these groups, we chose to list the species and discuss according to classifications consolidated in literature. Thus, we followed Jacobson \& Weller (2002) for Arctiinae, Kitching \& Rawlins (1999) for Lymantriinae and Poole (1989) for other noctuid moths.

Periodicity and survey areas. The catches took place in two areas in the county of Bento Gonçalves (Vale dos Vinhedos, at $29^{\circ} 10^{\prime} 9.34^{\prime \prime}$ ' $; 51^{\circ} 33^{\prime} \mathrm{W}$ and Pinto Bandeira, at $29^{\circ} 4^{\prime} 42.08^{\prime \prime} \mathrm{S}$; $51^{\circ} 27^{\prime} \mathrm{W}$ ) and one in the county of Farroupilha (Linha Jacinto, at 296'51.91'’S; 51 ${ }^{\circ} 23^{\prime} \mathrm{W}$ ) with weekly periodicity, from November $27^{\text {th }}, 2007$ to March 29 2008. In Pinto Bandeira and Farroupilha, besides the cultivation of grapes, there were many kinds of temperate fruits, such as peach, plum, khaki, kiwi fruit etc., whereas in Vale dos Vinhedos there were mainly grapes. There were extensive cultivated forests of Eucalyptus and Acacia in all three areas, besides a few remaining native forest islands.

Survey with light traps. A Pennsylvania model light trap (Frost 1957) powered by 12 volt battery and equipped with fluorescent lamp F15T12LN (Sylvania) with wavelength varying from 290 to 450 nanometers with peak around 340 nanometers was settled in each area. It was attached in the lower part of each trap a plastic conic shaft and a bucket containing $3 \mathrm{~L}$ of $70 \%$ ethanol (Specht et al. 2005). The traps were hung at about $2 \mathrm{~m}$ high above the soil level and switched on from late afternoon to early morning, left for approximately twelve hours during one night per week.

Survey with McPhail traps. Six McPhail traps individually baited with $200 \mathrm{~g}$ of attractive medium were settled randomly in each area. The attractive bait was made up of a mixture of 2 $\mathrm{kg}$ of fruits, including grape, apple and peach, $1 \frac{1 / 2}{\mathrm{~L}}$ of white beer, $1 \mathrm{~L}$ of water and $1 \frac{1}{2} \mathrm{~kg}$ of sugar, maintained at $30^{\circ} \mathrm{C}$ by one day (Biezanko 1938). The traps were hung about $2 \mathrm{~m}$ high above the soil level and remained baited one night a week at the same period, however with a considerable distance from the light trap (>100 m). The food bait was collected every catch and reused twice before disposal and replacement with fresh bait.

Sorting and specimens identification. The samples obtained were sorted at the Laboratório de Biologia of the Universidade de Caxias do Sul (UCS), Campus Universitário da Região dos Vinhedos (CARVI). Representative specimens of each taxa were pinned and deposited in the Coleção da Universidade de Caxias do Sul (CUCS) as voucher specimens. The generic and when possible specific identifications were based on publications and examination of collections cited by Specht \& Corseuil (1996, 1998, 2001, 2002a), Specht et al. (2004) and Teston \& Corseuil (2002, 2003a, b).

Morphological analysis. The mouth-parts (proboscis) of each taxa collected were removed and analyzed under stereomicroscope with $60 \mathrm{x}$ magnification to search for evidence of their piercing suitability. Proboscises of representative species were dehydrated in $100 \%$ ethanol, followed by immersion in acetone for 15 minutes. To assure integrity of the proboscises, the water content of the samples was substituted by liquefied carbonic gas (Castro 2002) using critical point device Bal-Tech CPD030. Each proboscis was placed on an individual stub and fixed with carbon doublefaced adhesive tape than sputter-coated with carbon and gold. The samples were analyzed under a scan electron microscope Philips XL 30 Series, at the Centro de Microscopia e Microanálises (CEMM) of Pontifícia Universidade Católica do Rio Grande do Sul (PUCRS).

Data analysis. The data relative to the samples collected with the light and McPhail traps were organized according to occurrence and abundance of each taxa in each area, following alphabetical order by subfamily, tribe, sub-tribe, genus and species, considering, when possible, lower taxa as already mentioned (Tables I, II).

\section{RESULTS AND DISCUSSION}

Survey with light traps. A total of 3.007 noctuid moths of 187 taxa (Table 1) were collected from November 27 $7^{\text {th }}, 2007$ to March $29^{\text {th }}$, 2008. Arctiinae and Lithosinae represented $31.8 \%$ of total individuals, including 74 taxa with 15 identified at genus and 59 at species level. Episcea extravagans Warren, 1901 is registered for the first time in Rio Grande do Sul. The number of specimens identified at species level corresponds to $15.26 \%$ of total Arctiinae referred to in Rio Grande do Sul (Ferro \& Teston 2009). The relatively low percentage of Arctiinae species obtained in this study in relation to the ones referred to in Rio Grande do Sul may be attributed to the short period and dry weather during the survey. The lower catches may also be ascribed to the fewer sampling points in our research compared to the number recorded by Teston \& Corseuil (2004) who obtained higher species richness 


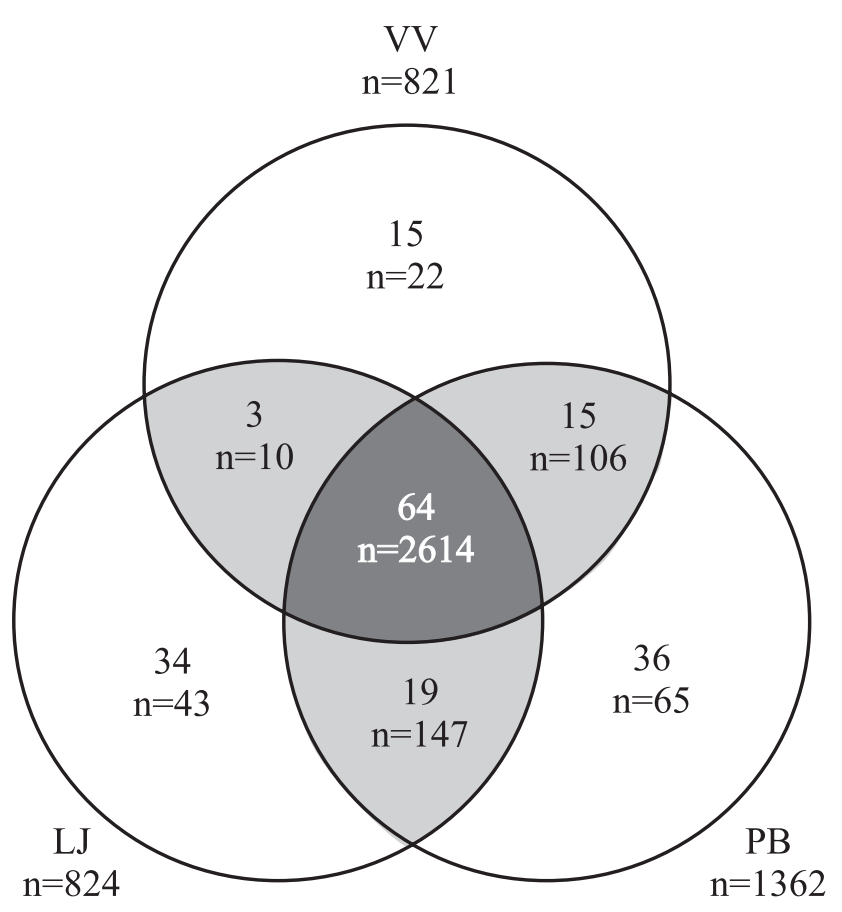

Fig. 1. Diagram of noctuid moths abundance and species richness in Linha Jacinto (LJ) (Farroupilha-RS), Pinto Bandeira (PB), and Vale dos Vinhedos (VV) (Bento Gonçalves-RS) captured with light traps during grape ripening period, from November 2007 to March 2008. Taxa with occurrence in one area are in white; in two areas are light gray; in three areas are dark gray.

in several different regions of Rio Grande do Sul during a two year survey and under variable climatic conditions. On another survey, Teston et al. (2006) obtained even higher species richness in a single night sampling than we obtained in four months. However, those authors's survey was carried out in conservation areas, what depicts that Arctiinae diversity depends on the degree of the environment conservation.

About $67 \%$ of the collected moths belonged to Noctuidae, grouped in 14 subfamilies sensu Poole (1989). This family represented the taxon with the highest richness in this survey, with 89 taxa identified to species level and 21 up to genus. The number of taxa identified at specific level corresponds to $19.82 \%$ of total Noctuidae referred to in Rio Grande do Sul (Specht \& Corseuil 1996, 1998, 2001, 2002a; Specht et al. 2004). In relation to specific richness, it should be noted that Specht \& Corseuil (2002b) obtained a similar result sampling in a contiguous area, even with systematic sampling for a considerably longer period of time. This discrepancy may be derived from climatic peculiarities, which happened during both surveys. On the other hand, Specht et al. (2005) obtained, in a single night in conservation areas of Rio Grande do Sul, higher species richness than that obtained in our survey. Once more, depicting the importance of environment conditions to favor diversity of Noctuidae sensu Poole (1989), as noted by Kitching et al. (2000).

Less than one percent of total noctuid moths collected belonged to Lymantriinae, with only two species and one genus identified. The only species captured with more than one specimen in all three areas was Thagona tibialis (Walker,
1855), and just one specimen of Sarcina violacens (HerrichSchaeffer, 1856) and one of Sarcina sp. were captured in Linha Jacinto (Table I). Due to lack of references about diversity of Lymantriinae, especially of Neotropical species (Kitching \& Rawlins 1999) no comparisons on diversity were made.

The highest abundance was recorded in Pinto Bandeira ( $n=1362)$, followed by Linha Jacinto $(n=824)$ and Vale dos Vinhedos ( $\mathrm{n}=821)$ (Table I). It was verified differences in species composition in all three areas, as observed in conservation areas by Specht et al. (2005) and Teston et al. (2006). Linha Jacinto and Pinto Bandeira presented more than twice as many exclusive species than Vale dos Vinhedos (Fig. 1). The three surveyed areas presented similar numbers of simultaneous species; however, Linha Jacinto and Vale dos Vinhedos shared a much smaller number of species (Fig. 1). This difference in species composition can be attributed to predominance of grape orchards in Vale dos Vinhedos, whereas in Pinto Bandeira and Linha Jacinto there are also other fruits species being cultivated.

By analyzing the proboscis it was verified that only Oraesia argyrosema (Hampson, 1926) (Ophiderinae sensu Poole 1989) (Fig. 2) shows morphological adaptations capable of causing primary damage to the grape berries. The proboscis of this species (Fig. 3) is endowed with several inherent characteristics of primary fruit-piercing moths described by Bänziger (1970): thick cuticle; end portion sharp and cover with cuticular spines curved to the head used to tear the rind of fruits; the presence of probably erectable sensilla in lateral region of each galea; presence of rasping spines in dorsal edge of each galea, which are used to lacerate the pulp of fruit and increase the stability between both galeae.

Besides $O$. argyrosema, many species which were previously included in Catocalinae or Opiderinae sensu Poole (1989) and referred to in Rio Grande do Sul (Specht \& Corseuil 1996, 1998, 2001; Specht et al. 2004) are nowadays included in Calpinae (Fibiger \& Lafontaine 2005). Those species are included in the following genera: Alabama Grote, 1895; Anomis Hübner, 1816; Anoba Walker, 1858; Eudocima Billberg, 1820; Goniapterix Petry, 1833; Gonodonta Hübner, 1818; Litoprosopus Grote, 1869; Plusiodonta Guenée, 1852; and Radara Walker, 1862. The members of Calpinae are the true fruit-piercing moths due to their specialized proboscis (Speidel et al. 1996) which is capable to cause primary damage.

Some species of Achaea Hübner [1823], Mocis Hübner [1823] and Ophisma Guenée, 1852, not included in Calpinae by Lafontaine \& Fibiger (2006), are referred either as primary or secondary piercers in Thailand (Bänziger 1982). However, the species included in these genera which were collected in this survey: Acahea ablunaris (Guenée, 1852), Mocis latipes Hübner, 1823, and Ophisma tropicalis Guenée, 1852 showed proboscis poorly adapted for piercing (Figs. 7, 8 and 9). Excepting in A. ablunaris, which shows a very sharp tip adapted for piercing soft rind fruits, the proboscis tips of the other species are relatively less sharp and endowed in dorsal edge, with rasping spines and sensilla which can probably act like rasping spines. Thus, these species are only capable to penetrate fruits by pre-existing holes in the berry. This 

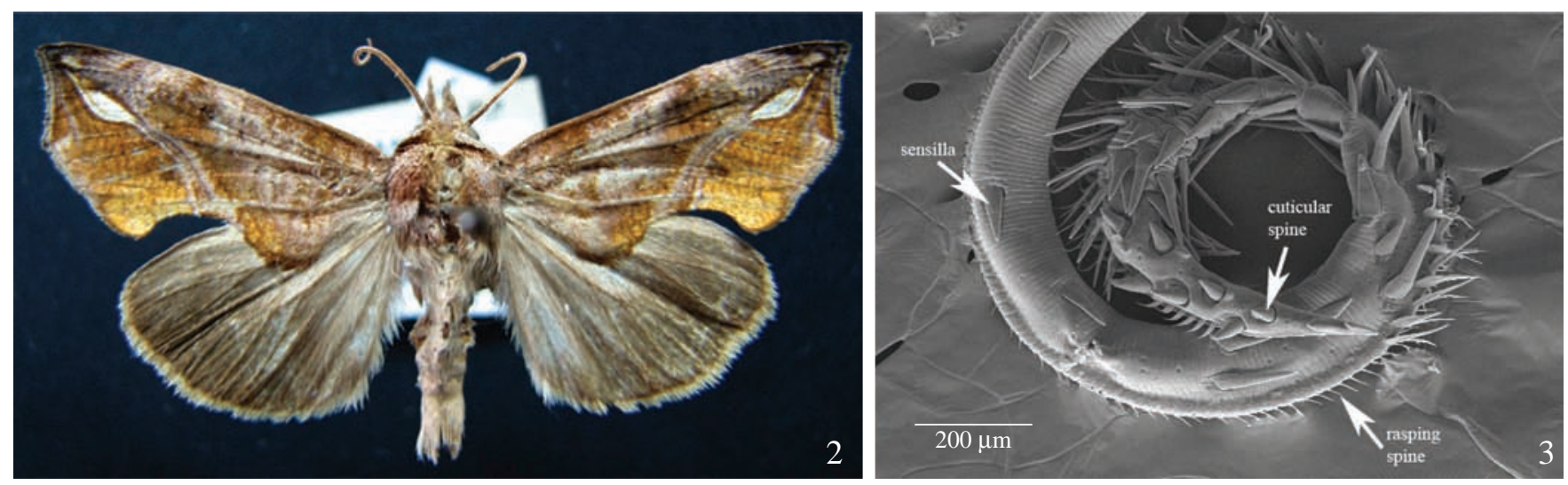

Figs. 2-3. Oraesia argyrosema - 2, Adult male; 3, proboscis tip.

kind of damage, characterized as secondary, may not be so important, since a primary damage must be already done. Notwithstanding, microorganisms present in the opened rind can be inoculated, accelerating the decay process (Bänziger 1982). Other species collected in this survey and not included in Calpinae by Lafontaine \& Fibiger (2006) that may cause secondary damage are Ascalapha odorata (Linnaeus, 1758), Letis mineis Geyer, 1827, and Zale exhausta (Guenée, 1852) (Table I). These noctuid moths show proboscis tips with sensilla very similar to those found in fruit feeding Nymphalidae butterflies (Figs. 10, 11 and 12) (Krenn et al. 2001; Knopp \& Krenn 2003).

It worthy emphasizing that in Rio Grande do Sul, in addition to the previously mentioned species there are four more included in the genus Mocis [1823], three in Ophisma Guenée, 1852, nine in Letis Lepeletier \& Serville, 1828, and seven in Zale Hübner, 1818 (Specht \& Corseuil 1996, 2001, 2002a; Specht et al. 2004), which probably show similar proboscises.

In relation to distinction between primary and secondary fruit-piercing moths, Bänziger (1982) mentions that even species with similar proboscises may show different piercing capability, since there are other factors than morphology of apical armature that contribute for piercing. Thus, to assess the piercing capability of a species with no doubt, specimens must be kept in a recipient with intact fruits. If the fruits are pierced after some days the species should be referred as primary for that kind of fruit.

The reduced number of specimens captured of previously mentioned species (Table I) can be attributed to climatic conditions, since the survey period was characterized as a very dry season. Similar observations were made by Bänziger (1982), who reports that populations of fruit-piercing moths are generally higher during rainy season in Thailand. Therefore, would be expected a much larger fruit-piercing moth species diversity, since there are twenty five Calpinae species referred to in Rio Grande do Sul (Specht \& Corseuil 1996, 1998, 2001; Specht et al. 2004. However, periodic surveys of Noctuidae (Specht \& Corseuil 2002b; Specht et al. 2005) show both low species richness and abundance of Calpinae species. The findings from this study suggest that for a complete evaluation of fruit-piercing moth populations, the catches should be done in several other regions with distinct climatic conditions, in other cultivated fruit orchards, along the seasons, and the study of larva feeding behavior and interactions between moths, host plants and natural enemies.

The species included in the remaining subfamilies could not cause primary or secondary damages, since their proboscises are not adapted for that behavior. All Plusiinae (Table I), in agreement with Speidel et al. (1996), show proboscis tip less sharp and with fewer and smaller cylindrical sensilla, as verified in Rachiplusia nu (Guenée, 1852) (Fig. 13), suggesting probably nectivorous feeding habits (Bänziger 1982). The proboscis of Tripseuxoa strigata Hampson, 1903 (Fig. 14) and those of species include in Paracles Walker, 1855 are less developed, indicating reduced or completely lack of feeding in adult stage.

The other noctuid moths surveyed show proboscis tip with cylindrical lateral sensilla and lamelliform structures on the dorsal portion of each galea edge with slight variation in number, form and size, as verified in Bleptina confusalis Guenée, 1852 (Fig. 15), Anticarsia gemmatalis Hübner, 1818 (Fig. 16), and Cosmosoma auge (Linnaeus, 1767) (Fig. 17).

It is noteworthy the presence of stamen attached to the proboscis of specimens of Chabuata major (Guenée, 1852) and Heterochroma sp. (Fig. 18), indicating nectivorous feeding habit, which is common among noctuid moths (Lingren et al. 1993; Hendrix et al. 1987). According to Bänziger (1982), it is not impossible, even for this species which have fewer and smaller sensilla, to scrap the exposed pulp of damaged fruits and feed on them. In the same way, many lepidopterans with well developed proboscises may explore several food sources, including damaged grapes with out-flowing liquid, to obtain mainly water, sugars, salts, and amino acids (Scoble 1995).

The lymantriid moths, as known, have very reduced mouth-parts, with no trace of proboscis (Scoble 1995) and, therefore, do not feed and are unable to inflict fruit damage, such as the species detected in this survey (Table I).

Therefore, we can not assume a priori that the occurrence of species with more than 100 specimens (Table I) is not associated (or at least partially associated) with available 

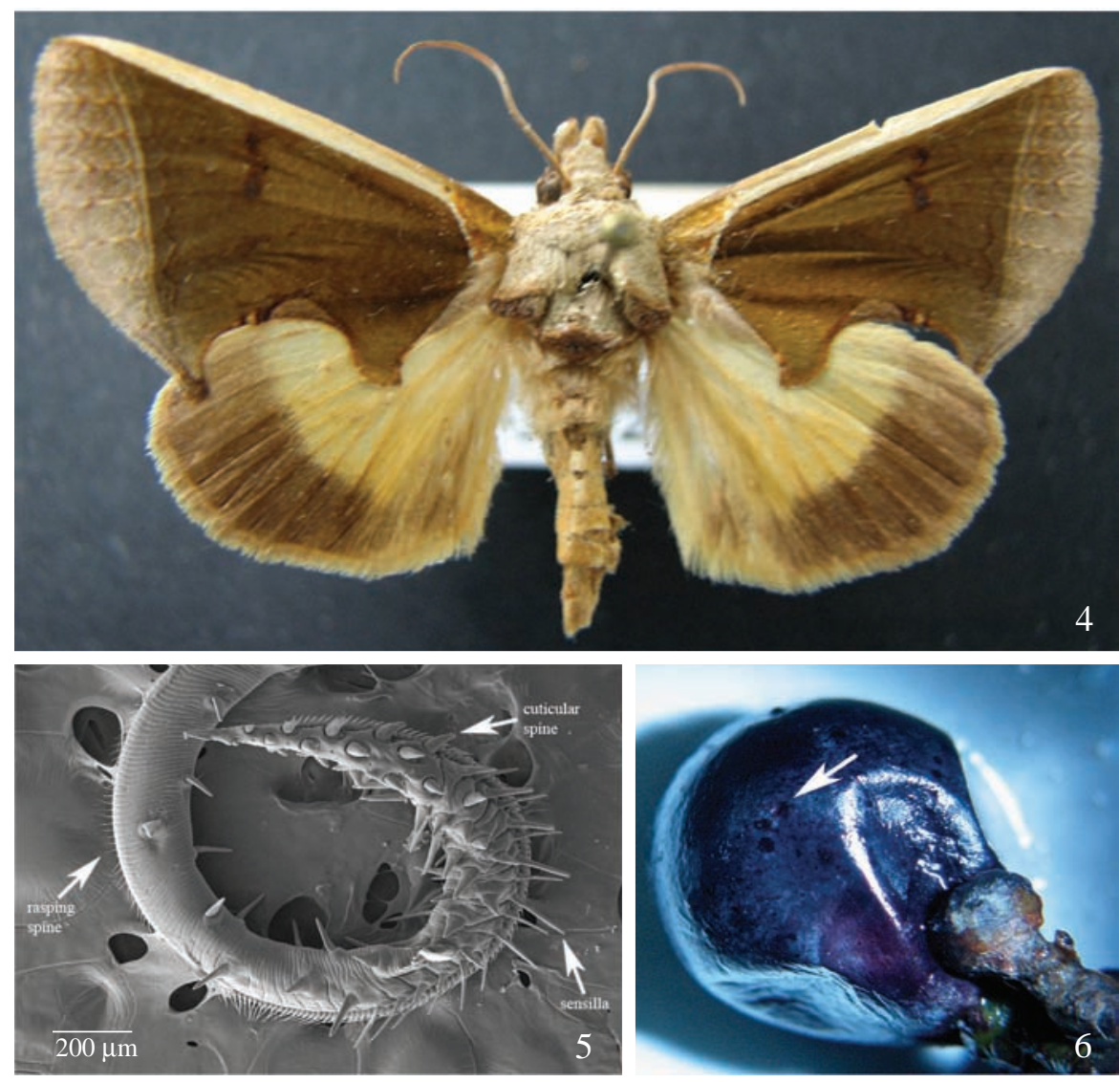

Figs. 4-6. Gonodonta biarmata - 4, Adult female; 5, proboscis tip; 6, grape berry pierced by the moth.

damaged berries which can be use as food. However, this hypothesis is very unlikely because the occurrence of those species is associated with the presence of host plant for the larvae, since the majority of the species, excepting $B$. confusalis, are polyphagous and associated with cultivated plant groups and common grasses as ryegrass (Lolium multiflorim Lam.) (Specht \& Corseuil 2002b).

Survey with McPhail traps. A total of 143 specimens belonging to four species (Table II) were collected in McPhail traps, including a single specimen of $A$. gemmatalis and three of Gonodonta biarmata Guenée, 1852. Together, C. major and $B$. confusalis represented $97.2 \%$ of the trapped specimens. Vale dos Vinhedos showed higher species abundance than the other areas (Table II).

The large number of $B$. confusalis may be associated to the presence of damaged berries in the grape orchards, which can be a potential food source. Another explanation is related to the large amount of organic matter normally found in agroecosystems, which is probably used as food by Herminiinae larvae (Kitching \& Rawlins 1999). In the same way, the presence of a high number of $C$. major specimens can be associated to the presence of damaged berries. However, a more logical explanation would be that the polyphagous larvae C. major have plenty of food from corn, lettuce, carrot, and beet crops (Teran 1974) found in the surveyed area.

The only species collected exclusively in the McPhail traps was G. biarmata (Fig. 4), with one specimen captured in each area (Table II). This species belongs to Calpinae and show proboscis (Fig. 5) very similar to O. argyrosema, thus can potentially cause primary damage to grapes. Its capacity to cause damage was proven by a simple experiment, which one of the specimen collected during the catches was maintained in a recipient with intact grape berries, and by the fifth day it was verified characteristic perforations (Fig. 6), indicating that the moth had pierced the rind to feed on. Catches of G. biarmata in the traps do not mean that this species is associated to the grape orchard, but eventually to the khaki plants [Diospyros kaki L. - Ebenaceae] in nearby orchards (Silva et al. 1968; Specht et al. 2004; Todd 1959) which are host plants for its larvae.

Despite the extensive areas of $D$. kaki, the number of G. biarmata moths was extremely low in the McPhail traps (Table II). Like in the case of $O$. argyrosema, this fact may be attributed to the dry weather during the survey period or to the action of parasitoids and diseases. Observations made by the entomologist Ceslau Biezanko, from 1948 to 1970, indicated that G. biarmata was already rare in south Brazil (Specht et al. 2004), what may be an indication of naturally reduced populations. Another explanation for the low abundance verified is related to the reduced preserved native forest nearby the survey areas, where native fruit species are found, such as the Myrtaceae araçá [Psidium cattleianum Sabine], guava [Psidium guajava L.], guaviroba [Campomanesia xanthocarpa O. Berg], and pitanga [Eugenia 
Table I. Noctuid moths captured weekly with light traps in Linha Jacinto (LJ) (Farroupilha), Pinto Bandeira (PB), and Vale dos Vinhedos (VV) (Bento Gonçalves-RS) during grape ripening period, from November 2007 to March 2008.

Taxa LJ PB VV Total

Acontiinae (sensu Poole, 1989)

1. Acontia ardoris (Hübner [1827-1831])

2. Acontia ruffinellii Biezanko (1959)

3. Cydosia rimata Draudt, 1927

4. Lithacodia mella Schaus (1894)

Acronictinae (sensu Poole, 1989)

5. Calymniodes conchylis (Guenée, 1852)

Amphipyrinae (sensu Poole, 1989)

6. Antachara diminuta (Guenée, 1852)

7. Antachara sp.

8. Bryolymnia bicon (Druce, 1889)

9. Callopistria floridensis (Guenée, 1852)

10.Condica cupentia (Cramer, 1780)

11. Condica selenosa (Guenée, 1852)

12.Condica stelligera (Guenée, 1852)

13. Condica sutor (Guenée, 1852)

14.Cropia plumbicincta Hampson, 1908

15.Elaphria agrotina (Guenée, 1852)

16.Elaphria deltoides (Möschler, 1880)

17.Elaphria jalapensis (Schaus, 1894)

18.Elaphria jonea (Schaus, 1906)

19.Elaphria marmorata (Schaus, 1894)

20.Elaphria subobliqua (Walker, 1858)

21.Elaphria sp. 1

22.Elaphria sp. 2

23.Elaphria sp. 3

24.Elaphria villicosta (Walker, 1858)

25.Hampsonodes naevia (Guenée, 1852)

26.Hampsonodes sp. 1

27.Hampsonodes sp. 2

28.Hampsonodes sp. 3

29.Hampsonodes sp. 4

30.Heterochroma chlorographa Hampson, 1908

31. Heterochroma sp.

32.Magusa orbifera (Walker, 1857)

33.Phosphila lacruma (Schaus, 1894)

34.Phuphena petrovna (Schaus, 1894)

35.Phuphena transversa (Schaus, 1894)

36.Pseudina albina Hampson, 1910

37.Spodoptera albula (Walker, 1857)

38.Spodoptera cosmioides (Walker, 1858)

39.Spodoptera dolichos (Fabricius, 1794)

40.Spodoptera eridania (Stoll, 1782)

41.Spodoptera frugiperda (J. E. Smith, $6 \quad \begin{array}{llll}6 & 21 & 25 & 52\end{array}$ 1797)

42.Spodoptera marima (Schaus, 1904)

43.Trachea anguliplaga (Walker, 1858)

Catocalinae (sensu Poole, 1989)

44.Achaea ablunaris (Guenée, 1852)

45.Mocis latipes Hübner, 1823

46.Ophisma tropicalis Guenée, 1852

47.Perasia sp.

48.Ptichodes basilans (Guenée, 1852)

49.Zale exhausta (Guenée, 1852)
Table I. Cont.

\begin{tabular}{lllll}
\hline Taxa LJ & PB & VV & Total \\
\hline
\end{tabular}

Bagisarinae (sensu Poole, 1989)

50.Bagisara repanda (Fabricius, 1793)

51.Bagisara sp.1

52.Bagisara sp. 2

Ophiderinae (sensu Poole, 1989)

53.Anticarsia gemmatalis Hübner, 1818

54.Ascalapha odorata (Linnaeus, 1758)

55.Coenipeta bibitrix (Hübner, 1823)

56.Coenipeta zenobina (Massen, 1890)

57.Hypocala andremona (Stoll, 1781)

58.Melipotis fasciolaris (Hübner, 1831)

59.Selenisa sueroides (Guenée, 1852)

60.Eulepidotis detracta (Walker, 1858)

61.Eulepidotis sp.

62.Encruphion leena (Druce, 1898)

63.Herminodes renicula (C. Felder \&

Rogenhofer, 1874)

64.Letis mineis Geyer, 1827

65.Licha undilinealis Walker, 1850

66.Oraesia argyrosema (Hampson, 1926)

Cuculiinae (sensu Poole, 1989)

67.Cucullia argyrina Guenée, 1852

68.Neogalea sunia (Guenée, 1852)

Euteliinae (sensu Poole, 1989)

69.Eutelia abscondens (Walker, 1858)

70.Paectes devincta (Walker, 1858)

Hadeninae (sensu Poole, 1989)

71.Chabuata major (Guenée, 1852)

72.Dargida meridionalis (Hampson, 1905)

73.Eriopyga approximans Jones, 1908

74.Eriopyga sp. 1

75.Eriopyga sp. 2

76.Eriopyga sp. 3

77.Faronta albilinea (Hübner, 1821)

78.Leucania albifasciata (Hampson, 1905)

79.Leucania humidicola Guenée, 1852

80.Leucania jaliscana Schaus, 1898

81.Leucania latiuscula Herrich-Schäffer, 1868

82.Leucania microsticha (Hampson, 1905)

83.Leucania sp. 1

84.Orthodes curvirena (Guenée, 1852)

85.Orthodes sp. 1

86.Orthodes sp. 2

87.Polia sp.

88.Pseudaletia adultera (Schaus, 1894)

89.Pseudaletia sequax Franclemont, 1951

Heliothinae (sensu Poole, 1989)

90.Helicoverpa gelotopoeon (Dyar, 1921)

91.Helicoverpa zea (Boddie, 1850)

92.Heliothis tergemina (C. Felder \&

Rogenhofer, 1874)

93.Heliothis virescens (Fabricius, 1777)

Herminiinae (sensu Poole, 1989)

94.Bleptina confusalis Guenée, 1852

$\begin{array}{cccc}2 & 3 & 6 & 11 \\ 2 & & & 2 \\ & 1 & & 1 \\ 4 & 4 & 6 & 14\end{array}$

$\begin{array}{llll}20 & 65 & 22 & 107\end{array}$

$\begin{array}{llll} & 1 & 1 & 2 \\ 1 & 2 & 6 & 9\end{array}$

$1 \quad 1$

$2 \quad 1 \quad 3-3$

11

$1 \quad 1$

11

$\begin{array}{ll}1 & 1 \\ 1 & 1\end{array}$

$\begin{array}{cccc} & 1 & 1 & 2 \\ 1 & 1 & & 2 \\ 1 & 1 & & 2 \\ 25 & 74 & 39 & 138\end{array}$

$\begin{array}{llll} & 1 & & 1 \\ 1 & & 2 & 3 \\ 1 & 1 & 2 & 4\end{array}$

123

$1 \quad 1$

$2 \quad 24$

$\begin{array}{llll}15 & 20 & 8 & 43\end{array}$

$\begin{array}{lll}1 & 1\end{array}$

$\begin{array}{llll}13 & 11 & 4 & 28\end{array}$

$\begin{array}{llll}2 & 2 & 1 & 3 \\ 2 & & & 2\end{array}$

$\begin{array}{lll}1 & & 1\end{array}$

$\begin{array}{llll}32 & 42 & 54 & 128\end{array}$

$\begin{array}{lll}2 & 1 & 3\end{array}$

$\begin{array}{llll}25 & 27 & 35 & 87\end{array}$

$\begin{array}{llll}1 & 1 & 2 & 4\end{array}$

$\begin{array}{lll}32 & 13 & 45\end{array}$

$4 \quad 4$

$\begin{array}{llll}20 & 21 & 22 & 63\end{array}$

$\begin{array}{llll}71 & 98 & 70 & 239\end{array}$

1820

$\begin{array}{lll}4 & 1 & 5\end{array}$

$3 \quad 3$

$\begin{array}{llll}9 & 18 & 26 & 53\end{array}$

$\begin{array}{llll}211 & 292 & 237 & 740\end{array}$

$\begin{array}{ccccc} & & 1 & & 1 \\ & 9 & 11 & 41 & 61 \\ 8 & & 1 & & 1\end{array}$

$\begin{array}{lll}2 & 2 & 4\end{array}$

$\begin{array}{llll}11 & 13 & 43 & 67\end{array}$

$\begin{array}{llll}77 & 82 & 95 & 254\end{array}$ 
Table I. Cont.

\begin{tabular}{lcccc}
\hline Taxa & LJ & PB & VV & Total \\
\hline 95.Bleptina sp. & 1 & & & 1 \\
& 78 & 82 & 95 & 255
\end{tabular}

Noctuinae (sensu Poole, 1989)

96.Agrotis ipsilon (Hufnagel, 1766)

97.Agrotis subterranea (Fabricius, 1794)

98.Anicla ignicans (Guenée, 1852)

99.Anicla infecta (Ochsenheimer, 1816)

100.Ochropleura cirphisioides Köhler, 1955

101.Peridroma saucia (Hübner, 1808)

102.Pseudoleucania butleri (Schaus, 1898)

103.Pseudoleucania messium (Guenée, 1852)

104.Tandilia rodea (Schaus, 1894)

105.Tripseuxoa strigata Hampson, 1903

Plusiinae (sensu Poole, 1989)

106.Autographa bonaerensis (Berg, 1882)

107.Autoplusia oxygramma

108.Plusia admonens Walker, 1858

109.Rachiplusia nu (Guenée, 1852)

Sarrothripinae (sensu Poole, 1989)

110.Iscadia aperta Walker, 1857

Arctiinae (sensu Jacobson \& Weller, 2002)

Arctiini (sensu Jacobson \& Weller, 2002)

111.Hypercompe heterogena (Oberthür, 1881)

112.Hypercompe sp.

113.Isia alcumena (Berg, 1882)

114.Paracles bilinea (Schaus, 1901)

115.Paracles fervida (Schaus, 1901)

116.Paracles fusca (Walker, 1856)

117.Paracles sp.

118.Paracles variegata (Schaus, 1896)

119.Virbia divisa (Walker, 1864)

Ctenuchini (sensu Jacobson \& Weller, 2002)

120.Aclytia heber (Cramer, 1780)

121.Aclytia terra Schaus, 1896

122.Argyroeides sanguinea Schaus, 1896

123.Delphyre roseiceps Dognin, 1909

124.Delphire sp.

125.Episcepsis endodasia Hampson, 1898

126.Eucereon arenosum Butler, 1877

127.Eucereon discolor (Walker, 1856)

128.Eucereon rosa (Walker, 1854)

129.Eucereon sp.

130.Eucereon striatum (Druce, 1889)

131.Nelphe cofinis (Herrich-Schäffer, [1855])

132.Philoros affinis (Rothschild, 1912)

133.Theages leucophaea Walker, 1855

134.Tipulodes ima Boisduval, 1833

Euchromiini (sensu Jacobson \& Weller, 2002)

135.Aristodaema hanga (Herrich-Schäffer, [1854])

136.Cosmosoma auge (Linnaeus, 1767)

137.Cosmosoma centrale (Walker, 1854)

138. Cosmosoma sp.

139.Dycladia lucetius (Stoll, 1781)

140.Eurota helena (Herrich-Schäffer, 1854)

$\begin{array}{llll}62 & 101 & 52 & 215\end{array}$

$\begin{array}{cccc} & 1 & & 1 \\ 1 & & & 1 \\ 1 & 8 & 5 & 14 \\ 9 & 48 & 20 & 77 \\ 11 & 57 & 25 & 93\end{array}$

$\begin{array}{cccc}26 & 54 & 16 & 96 \\ & 1 & & 1 \\ & 1 & 2 & 3 \\ 34 & 69 & 25 & 128\end{array}$

$1 \quad 1$

$\begin{array}{cccc}3 & 1 & 1 & 5 \\ & 1 & 1 & 2 \\ 1 & 4 & & 5 \\ & 6 & 2 & 8 \\ 4 & 6 & 7 & 17\end{array}$

Table I. Cont.

\begin{tabular}{lcccc}
\hline Taxa & LJ & PB & VV & Total \\
\hline 141.Eurota herricki Butler, 1876 & 29 & 95 & 2 & 126 \\
142.Macrocneme sp. & & & 1 & 1
\end{tabular}

143.Phoenicoprocta analis Schrottky, 1909

144.Poliopastea sp.

145.Psilopleura sanguipuncta Hampson, 1898

146.Rhynchopyga meisteri (Berg, 1883)

147.Saurita cassandra (Linnaeus, 1758)

Pericopini (sensu Jacobson \& Weller, 2002)

148.Dysschema hilarina (Weymer, 1914)

149.Dysschema sacrifica (Hübner, [1831])

150.Episcea extravagans Warren, 1901

151.Euchlaenidia transcisa (Walker, 1854)

Phaegopterini (sensu Jacobson \& Weller, 2002)

152.Agaraea semivitrea Rothschild, 1909

153.Agaraea sp.

154.Baritius acuminata (Walker, 1856)

155.Bertholdia soror Dyar, 1901

156.Biturix rectilinea (Burmeister, 1878)

157.Demolis albicostata Hampson, 1901

158.Elysius pyrostica Hampson, 1905

159.Halysidota pearsoni Watson, 1980

160.Halysidota striata Jones, 1908

161.Hyalarctia sericea Schaus, 1901

162.Hyperthaema signatus (Walker, 1862)

163. Hyperthaema sp.

164.Hypidalia enervis (Schaus, 1894)

165.Idalus agastus Dyar, 1910

166.Leucanopsis coniota (Hampson, 1901)

167.Leucanopsis oruba (Schaus, 1892)

168.Leucanopsis sp.

169.Lophocampa sp.

170.Machadoia xanthosticta (Hampson, 1901)

171.Mazaeras conferta Walker, 1855

172.Mazaeras janeira (Schaus, 1892)

173.Melese chozeba (Druce, 1884)

174.Melese sp.

175.Neritos repanda Walker, 1856

176.Opharus procroides Walker, 1855

177.Ormetica chrysomelas (Walker, 1856)

178.Paraeuchaetes aurata (Butler, 1875)

179.Pelochita cinerea (Walker, 1855)

$\begin{array}{llll}3 & 1 & & 1 \\ & 1 & 1 & 5 \\ 1 & & 1\end{array}$

$\begin{array}{lll}1 & 2 & 3\end{array}$

$\begin{array}{llll}41 & 119 & 16 & 176\end{array}$

$\begin{array}{lll}1 & 1 & 2\end{array}$

$\begin{array}{llll}4 & 2 & 3 & 9\end{array}$

$\begin{array}{lll}6 & 18 & 24\end{array}$

$\begin{array}{llll}3 & 4 & 1 & 8\end{array}$

$\begin{array}{llll}14 & 25 & 4 & 43\end{array}$

180.Phaegoptera albimacula (Jones, 1908)

181.Symphlebia lophocampoides R. Felder, 1874

182. Symphlebia sp.

183. Tessellarctia semivaria (Walker, 1856)

Lithosiinae (sensu Jacobson \& Weller, 2002) 184. Agylla sp.

$\begin{array}{ccc}1 & & 6 \\ & & 1 \\ 13 & 14 & 35 \\ 22 & 5 & 40 \\ 2 & & 6 \\ 1 & & 1 \\ & & 2 \\ & & 1 \\ & & 1 \\ & & 1 \\ 1 & 3 & 5 \\ 1 & 1 & 19 \\ & & 1 \\ 2 & & 4 \\ 12 & 7 & 24 \\ & & 1 \\ 2 & 1 & 5 \\ 1 & 2 & 8 \\ 3 & 13 & 26\end{array}$

Lymantriinae (sensu Kitching \& Rawlins, 1999)

185. Sarcina sp.

186. Sarcina violacens (Herrich-Schaeffer, 1856)

187. Thagona tibialis (Walker, 1855)

2

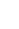

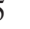

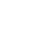



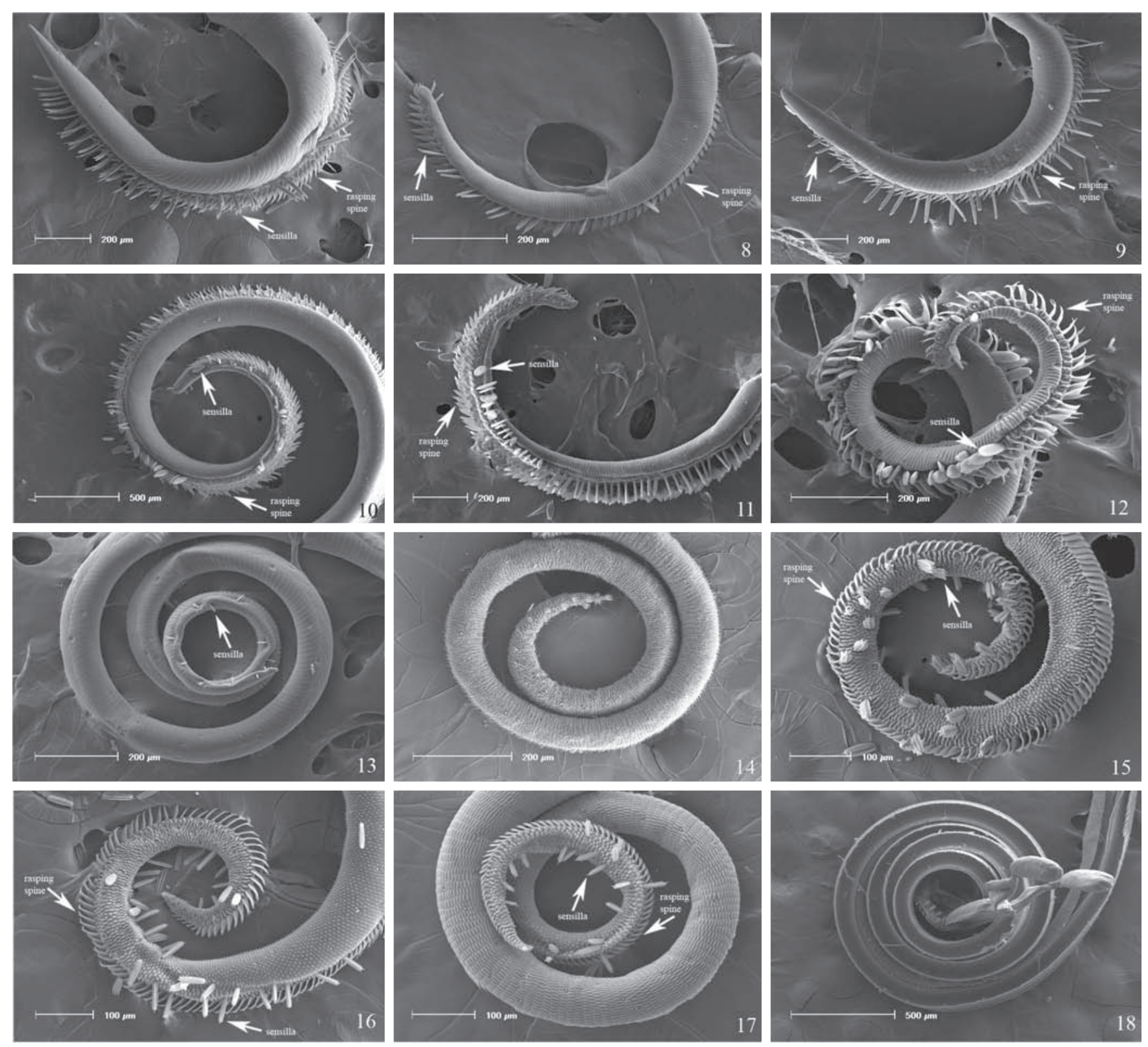

Figs. 7-18. Proboscis tips of Noctuidae moths: 7, Achaea ablunaris; 8, Mocis latipes; 9, Ophisma tropicalis; 10, Ascalapha odorata; 11, Letis mineis; 12, Zale exhausta; 13, Rachiplusia nu; 14, Tripseuxoa strigata; 15, Bleptina confusalis; 16, Anticarsia gemmatalis; 17, Cosmosoma auge; 18, Heterochroma sp.

uniflora L.], and the Annonaceae quaresma [Annona cacans Warm.], which can be serve as host plants for larvae and adult. In fact, some moths from the genus Gonodonta have already been observed piercing tropical native fruits as sugar apple [Annona squamosa L. Annonaceae] (Todd 1959). Among the plants reported as Gonodonta species host plants are orange, tangerine, and grapefruit (Todd 1959), which rots due to the several perforations made by the moths that let oxygen get inside. Damaged fruits can attract secondary fruit-piercing moths and be attacked by saprophytic flies and beetles (Todd 1959).

The McPhail trap was more effective than the light trap to study G. biarmata populations, though only three specimens have been captured. It can be attributed to the probably low attractiveness of $G$. biarmata to light, as verified in $E$. fullonia (Kumar \& Lal 1983). The bait composition and the period of time during which it was used before disposal and replacement may be contributed to the reduced abundance of fruit-piercing moths captured in McPhail traps. Landolt (1995) evaluated different kinds of baits to capture M. latipes and verified that different concentration baits show distinct degrees of attractiveness that is reduced by the third day of preparation. The bait composition and the fact that it was use for fifteen days may be negatively influenced the bait attractiveness. However, during the study of ecological aspects of fruit-piercing moths in Thailand, Ngampongsai et al. (2005) obtained high species diversity and relatively high abundance using pineapple pieces kept for one week in the traps. It worthy emphasize that in addition to the previously mentioned factors, the McPhail trap design would negatively 
Table II. Noctuid moths captured weekly with McPhail traps in Linha Jacinto (LJ) (Farroupilha), Pinto Bandeira (PB), and Vale dos Vinhedos (VV) (Bento Gonçalves-RS) during grape ripening period, from November 2007 to March 2008.

Taxa LJ PB VV Total

Noctuidae sensu Poole, 1989

Hadeninae

1. Chabuata major (Guenée, 1852)

$\begin{array}{llll}12 & 20 & 50 & 82 \\ 12 & 20 & 50 & 82\end{array}$

Herminiinae

2. Bleptina confusalis Guenée, $1852 \quad 4 \quad 4 \quad 6 \quad 47 \quad 57$

Ophiderinae

3. Anticarsia gemmatalis Hübner, 1818

4. Gonodonta biarmata Guenée, 1852

TOTAL

$\begin{array}{llll}4 & 6 & 47 & 57\end{array}$

$\begin{array}{cccc}1 & & & 1 \\ 1 & 1 & 1 & 3 \\ 2 & 1 & 1 & 4 \\ 18 & 27 & 98 & 143\end{array}$

affected the attractiveness; thus, it is necessary to compare the effectiveness of other kinds of traps.

As a conclusion, we found that among the noctuid species occurring in the studied grape orchards during fructification period, only a very low number of moths show proboscis with morphology able of causing primary fruit-damage, particularly the Calpinae species G. biarmata. Obviously, more studies about fruit-piercing moths in Brazil are needed, especially in fruit producer regions, aiming to find out the potentiality of these insects to cause damage. The most completely method to evaluate the fruit-piercing moth populations is using bait and light traps simultaneously, testing several kinds of traps and baits. Studies to determine the size and distribution of populations, immature stages, parasitoids and host plants of the larvae of fruit-piercing moths are needed. It is also important to do field nocturnal observations and laboratory experiments aiming to evaluate the piercing capacity of each species.

Acknowledgements. The authors acknowledge the financial support by $\mathrm{CNPq}$, and the following people that contributed to this paper: Aline Rodrigues, Augusto Jobim Benedetti, Casa Valduga Winery (Vale dos Vinhedos), Contini family (Linha Jacinto), Edegar Fronza, Dr. Gervásio Silva Carvalho, Graziela Poletto, Rosângela Brito, Rubbo Family (Pinto Bandeira), and Dra. Sonia Maria Noemberg Lazzari.

\section{REFERENCES}

Bänziger, H. 1970. The piercing mechanisms of the fruit-piercing moth Calpe [Calyptra] thalictri bkh (Noctuidae) with reference to the skin-piercing blood-sucking moth C. eustrigata Hmps. Acta Tropica 27: 54-88.

Bänziger, H. 1982. Fruit-piercing moths (Lep., Noctuidae) in Thailand: a general survey and some new perspectives. Mitteilungen der Schweizerischen Entomologischen Gesellschaft 55: 213-240.

Biezanko, C. M. 1938. Sobre as iscas que se usam para atrair lepidópteros e algumas outras questões que se relacionam com este assunto. Chácaras e quintais 58: $62-63$.

Castro, L. A. S. de. 2002. Processamento de amostras para microscopia eletrônica de varredura. Pelotas, Embrapa Clima Temperado, Documentos, 93, 37 p. Available at: <www.cpact.embrapa.br/ publicacoes/download/documentos/documento_93.pdf .>. Access 20/11/2008
Davis, E. E.; S. French \& R. C. Venette. 2005. Mini risk assessment - fruit piercing moth: Eudocima fullonia Green [Lepidoptera: Noctuidae]. USDA-CAPS, 43p. Available at: <www.aphis.usda.gov/plant_health/ plant_pest_info/pest_detection/downloads/pra/efulloniapra.pdf.>. Access 15/10/2008.

Fay, H.; \& K. H. Halfpapp. 2006. Fruit maturity and soundness relevant to feeding choice by fruit-piercing moths (Lepidoptera: Noctuidae) in citrus crops in northeast Australia. International Journal of Pest Management 52: 317-324.

Ferro, V. G. \& J. A. Teston. 2009. Composição de espécies de Arctiidae (Lepidoptera) no sul do Brasil: relação entre tipos de vegetação e entre a configuração espacial do hábitat. Revista Brasileira de Entomologia 53: $278-286$.

Fibiger, M. \& J. D. Lafontaine. 2005. A review of the higher classification of the Noctuoidea (Lepidoptera) with special reference to the Holarctic fauna. Buchreihe zur Entomologie 11: 7-92.

Frost, S. W. 1957. The Pennsylvania insect light trap. Journal of Economic Entomology 50: 287-292.

Haji, F. N. P.; A. N. Moreira; J. A. de Alencar \& F. R. Barbosa. 2001. Monitoramento de pragas na cultura da videira. Petrolina, Embrapa Semi-Árido, Documentos, 162, 29 p. Available at: http://www.cpatsa. embrapa.br/public_eletronica/downloads/SDC162.pdf

Hendrix, W. H. III; T. F. Mueller; J. R. Phillips \& O. K. Davis. 1987. Pollen as an indicator of long-distance movement of Heliothis zea (Lepidoptera: Noctuidae). Environmental Entomology 16: 1148-1151.

Jacobson, N. L. \& S. J. Weller. 2002. A cladistic study of the Arctiidae (Lepidoptera) by using characters of immature and adults. Lanham, Thomas Say Publications in Entomology (Monograph)/ Entomological Society of America, 98 p.

King, J. R. \& W. L. Thompson. 1958. Fruit Piercing Moth, Gonodonta nutrix (Cramer), attacks oranges in Florida. The Florida Entomologist 41: 61-65.

Kitching, R. L.; A. G. Orr; L. Thalib; H. Mitchell; M. S. Hopkins \& A. W. Graham. 2000. Moth assemblages as indicators of environmental quality in remnants of upland Australian rain forest. Journal of Applied Ecology 37: 284-297.

Kitching, I. J. \& J. E. Rawlins. 1999. The Noctuoidea, p. 355-401. In: N. P. Kristensen (ed. vol.). Lepidoptera, Moths and Butterflies. Volume 1: Evolution, Systematics, and Biogeography. In: M. Fischer (ed.). Handbook of Zoology. Volume IV Arthropoda: Insecta. Berlin, de Gruyter, $491 \mathrm{p}$.

Knopp, M. C. N. \& H.W. Krenn. 2003. Efficiency of fruit juice feeding in Morpho peleides (Nymphalidae, Lepidoptera). Journal of Insect Behaviour 16: 67-77.

Krenn H. W.; K. P. Zulka \& T. Gatschnegg. 2001. Proboscis morphology and food preferences in nymphalid butterflies (Lepidoptera: Nymphalidae) Journal of Zoology 254: 17-26.

Kumar, K. \& S. N. Lal. 1983. Studies on the Biology, Seasonal Abundance and Host-Parasite Relationship of Fruit Sucking Moth Othreis fullonia (Clerk) in Fiji. Fiji Agricultural Journal 45: 71-77.

Lafontaine, J. D. \& M. Fibiger. 2006. Revised higher classification of the Noctuoidea (Lepidoptera). The Canadian Entomologist 138: 610-635.

Landolt, P. J. 1995. Attraction of Mocis latipes (Lepidoptera: Noctuidae) to sweet baits in traps. The Florida Entomologist 78: 523-530.

Lingren, P. D.; V. M. Bryant Jr.; J. R. Raulstron; M. Pendleton; J. Westbrook \& G. D. Jones. 1993. Adult feeding host range and migratory activities of corn earworm, cabbage looper, and celery looper (Lepidoptera: Noctuidae) moths as evidenced by attached pollen. Ecology and Behavior 86: 1429-1439.

Mosse-Robinson, I. 1968. Fruit-Sucking Moths (Lepidoptera: Noctuidae). Australian Zoologist 14: 290-293.

Ngampongsai, A.; B. Barrett; S. Permkam; N. Suthapradit \& R. Nilla-or. 2005. A preliminary study on some ecological aspects of the fruit piercing moths in Songkhla Province of Southern Thailand. Songklanakarin Journal of Science and Technology 27: 1135-1145.

Poole, R. 1989. W. Noctuidae, p. 1015-1314. In: J. B. Heppner (ed.) Lepidopterorum Catalogus. New York, Brill, 1314 p.

Scoble, M. J. 1995. The Lepidoptera Form, Function and Diversity. New York, Oxford University Press, 404 p.

Silva, A. G. de A.; C. R. Gonçalves; D. M. Galvão; A. J. L. Gonçalves; J. Gomes; M. M. Silva \& L. Simoni. 1968. Quarto Catálogo dos insetos 
que vivem nas plantas do Brasil, seus parasitos e predadores. Tomo 1. parte 2 Insetos. Rio de Janeiro, Ministério da Agricultura, 622 p.

Specht, A. \& E. Corseuil. 1996. Lista documentada dos noctuídeos (Lepidoptera: Noctuidae) ocorrentes no Rio Grande do Sul, Brasil. Biociências 4: 131-170.

Specht, A. \& E. Corseuil. 1998. Novas ocorrências de noctuídeos (Lepidoptera, Noctuidae) no Rio Grande do Sul, Brasil. Biociências 6: 123-129.

Specht, A. \& E. Corseuil. 2001. Ocorrência de noctuídeos (Lepidoptera, Noctuidae) no Rio Grande do Sul, Brasil. Nota suplementar I. Biociências 9: 97-103.

Specht, A. \& E. Corseuil. 2002a. Ocorrência de noctuídeos (Lepidoptera, Noctuidae) no Rio Grande do Sul, Brasil. Nota suplementar II. Biociências 10: 169-74.

Specht, A. \& E. Corseuil. 2002b. Diversidade de noctuídeos (Lepidoptera, Noctuidae) em Salvador do Sul, Rio Grande do Sul, Brasil. Revista Brasileira de Zoologia 19: 281-298.

Specht, A.; E. J. E. Silva \& D. Link. 2004. Noctuídeos (Lepidoptera, Noctuidae) do museu entomológico Ceslau Biezanko, Departamento de Fitossanidade, Faculdade de Agronomia “Eliseu Maciel”, Universidade Federal de Pelotas, RS. Revista Brasileira de Agrociência 10: 389-409.

Specht, A.; J. A. Teston; R. A. Di Mare \& E. Corseuil. 2005. Noctuídeos (Lepidoptera, Noctuidae) coletados em quatro áreas estaduais de conservação do Rio Grande do Sul, Brasil. Revista Brasileira de Entomologia 49: 130-140.

Speidel, W.; H. Fänger \& C. M. Naumann. 1996. The surface microstructure of the noctuid proboscis (Lepidoptera: Noctuidae). Zoologischer Anzeiger 234: 307-315.

Teran, H. R. 1974. Fauna del Noroeste Argentino - Contribución al Conocimiento de los Lepidópteros Argentinos V. Chabuata major Guenée (Hterocera, Noctuidae). Acta Zoologica Lilloana 31: 9-17.

Teston, J. A. \& E. Corseuil. 2002. Arctiinae (Lepidoptera, Arctiidae) ocorrentes no Rio Grande do Sul, Brasil. Parte I. Pericopini. Biociências 10: 79-86.

Teston, J. A. \& E. Corseuil. 2003a. Arctiinae (Lepidoptera, Arctiidae) ocorrentes no Rio Grande do Sul, Brasil. Parte II. Arctiini, Callimorphini e Phaegopterini. Biociências 11: 69-80.

Teston, J. A. \& E. Corseuil. 2003b. Arctiinae (Lepidoptera, Arctiidae) ocorrentes no Rio Grande do Sul, Brasil. Parte III. Ctenuchini e Euchromiini. Biociências 11: 81-90.

Teston, J. A. \& E. Corseuil. 2004. Diversidade de Arctiinae (Lepidoptera, Arctiidae) capturados com armadilha luminosa, em seis comunidades no Rio Grande do Sul, Brasil. Revista Brasileira de Entomologia 48: 77-90.

Teston, J. A.; A. Specht; R. A. Di Mare \& E. Corseuil. 2006. Arctiinae (Lepidoptera, Arctiidae) coletados em unidades de conservação estaduais do Rio Grande do Sul, Brasil. Revista Brasileira de Entomologia 50: 208-286.

Todd, E. L. 1959. The fruit-piercing moth of the genus Gonodonta Hübner (Lepidoptera: Noctuidae). United States Department of Agriculture, Technical Bulletin $\mathrm{N}^{\circ}$ 1201. Washington D.C., Government Printing Office, 52 p., 12 plates. 